\title{
NITROGEN FERTILIZATION BY DEEP BEDDING SWINE PRODUCTION AND ITS EFFECTS ON DRY MATTER PRODUCTION AND ACCUMULATION OF NUTRIENTS BY MAIZE
}

\author{
ALESSANDRO T. CAMPOS ${ }^{1}$, ALESSANDRO V. VELOSO ${ }^{2}$, ENILSON B. SILVA ${ }^{3}$, \\ TADAYUKI YANAGI JÚNIOR ${ }^{4}$, MATHEUS C. MATTIOLI ${ }^{5}$
}

\begin{abstract}
The goal of this study was to evaluate the nitrogen fertilization as deep litter for pigs in order to produce biomass and accumulate nutrients by the corn. A deep litter made of rice husk as organic compound, from a commercial pig farm during finishing phase, was used. After three consecutive batches of pigs, the deep litter was subjected to a maturation period of 50 days, and samples of this material were taken for analysis of agronomic value. The experimental design was completely randomized with five replicates. The treatments consisted of doses of $0,75,150$ and $300 \mathrm{mg} \mathrm{dm}^{-3}$ of $\mathrm{N}$ of deep litter, as well as an additional treatment with ammonium sulfate, with a dosage of $150 \mathrm{mg} \mathrm{dm}^{-3}$ of $\mathrm{N}$. After 45 days, corn plants were harvested in order to evaluate the total dry weight and nutrient concentrations of their aerial parts. Dry matter increases were found with more application of deep litter. Regarding control fertilization, the use of increasing dosages of deep litter allowed accumulation of $\mathrm{K}$, reduced the availability of $\mathrm{P}, \mathrm{Ca}, \mathrm{Mg}, \mathrm{Zn}$ and $\mathrm{B}$ and did not alter the concentrations of $\mathrm{N}, \mathrm{Cu}, \mathrm{Fe}$ and $\mathrm{Mn}$.
\end{abstract}

KEYWORDS: Pig farming, pig facilities, alternative management, waste treatment, organic fertilizer, Zea mays.

\section{ADUBAÇÃO NITROGENADA NA FORMA DE CAMA SOBREPOSTA DE SUÍNO E SEUS EFEITOS NA PRODUÇÃO DE MATÉRIA SECA E ACÚMULO DE NUTRIENTES PELA PARTE AÉREA DO MILHO}

RESUMO: O objetivo deste trabalho foi avaliar a influência da adubação nitrogenada na forma de cama sobreposta de suíno, na produção de matéria seca e no acúmulo de nutrientes pelo milho. Foi utilizada cama sobreposta feita de casca de arroz como composto orgânico, proveniente de uma granja comercial de suínos em fase de terminação. Após a passagem de três lotes consecutivos de suínos, a cama sobreposta foi submetida a um período de maturação de 50 dias. Foram feitas amostragens deste material para a análise de valor agronômico. O delineamento experimental foi o inteiramente casualizado, com cinco repetições. Os tratamentos constituíram-se das dosagens de 0; 75; 150 e $300 \mathrm{mg} \mathrm{dm}^{-3}$ de $\mathrm{N}$ de cama sobreposta, bem como um tratamento adicional com sulfato de amônio, na dose de $150 \mathrm{mg} \mathrm{dm}^{-3}$ de N. Após 45 dias, as plantas de milho foram colhidas e avaliadas quanto ao teor de matéria seca total e teor de nutrientes na parte aérea das plantas. Foram observados incrementos na produção de matéria seca total por ocasião do aumento nas dosagens de cama sobreposta. Em relação à adubação-testemunha, a utilização de doses crescentes de cama sobreposta possibilitou acúmulo de K, reduziu a disponibilidade de P, Ca, Mg, B e Zn, bem como não alterou as concentrações de $\mathrm{N}, \mathrm{Cu}, \mathrm{Fe}$ e $\mathrm{Mn}$.

PALAVRAS-CHAVE: Suinocultura, instalações para suínos, manejo alternativo, tratamento de dejetos, adubo orgânico, Zea mays.

\footnotetext{
${ }^{1}$ Professor Associado, Setor de Construções e Ambiência, Depto. de Engenharia, Universidade Federal de Lavras (DEG/UFLA). Coordenador do Grupo de Pesquisa em Construções e Ambiência em Biossistemas (COAMBI), campos@deg.ufla.br.

${ }^{2}$ Professor Substituto, Setor de Construções e Ambiência, Depto. de Engenharia, Universidade Federal de Lavras (DEG/UFLA).

Membro do Grupo de Pesquisa em Construções e Ambiência em Biossistemas (COAMBI), veloso.alessandrovieira@yahoo.com.br.

${ }^{3}$ Professor Associado, Departamento de Agronomia, Universidade Federal dos Vales do Jequitinhonha e Mucuri (FCA/UFVJM).

${ }^{4}$ Professor Associado, Setor de Construções e Ambiência, Depto. de Engenharia, Universidade Federal de Lavras (DEG/UFLA).

Membro do Grupo de Pesquisa em Construções e Ambiência em Biossistemas (COAMBI).

${ }^{5}$ Estudante de Graduação em Agronomia pela Universidade Federal de Lavras. Membro do Grupo de Pesquisa em Construções e Ambiência em Biossistemas (COAMBI).

Recebido pelo Conselho Editorial em: 14-3-2012
}

Aprovado pelo Conselho Editorial em: 21-5-2013 


\section{INTRODUCTION}

Swine production has economic, social and cultural relevance. The current structure of the productive systems of pigs with the concentration of animals in small areas, generates large amounts of waste and the activity has been criticized for contributing to environmental pollution (AITA et al., 2006a; ANGONESE et al., 2006; ANGONESE et al., 2007; CORDEIRO et al., 2007; DAL BOSCO et al., 2008a; DAL BOSCO et al., 2008b; SEDIYAMA et al., 2008; ORRICO JÚNIOR et al., 2009; SOUZA et al., 2009; SAMPAIO et al., 2010; SMANHOTTO et al., 2010; NUNES et al., 2011).

Commonly, the pig manure management is carried out in liquid form (AITA et al., 2007; SANTOS et al., 2007; AITA \& GIACOMINI, 2008; HIGARASHI et al., 2008), with the subsequent application of these residues in the soil (SANTOS et al., 2007; GIACOMINI \& AITA, 2008b; LIMON-ORTEGA et al., 2008; ORRICO JÚNIOR et al., 2009).

The use of pig liquid waste as a source of nutrients to the soil and crops occurs due to the high fertilizer potential of this type of waste (TAM, 1995; BASSO et al., 2005; AITA et al., 2006b). However, most pig farms are small areas and waste products are launched in doses that exceed the retention capacity of the soil (GATIBONI et al., 2008) and, thus, may occur the accumulation of nutrients, metals, pathogens, which may alter the quality of the soil and, of the water in case of leaching (NUNES et al., 2011).

In this context, one of the alternatives to the traditional management of pig manure in liquid form, introduced in Brazil in the 1990s, consists of housing animals in a deep litter system, that uses a deep bed composed of carbonaceous material with the function of absorbing and digest the liquid fraction of the waste when the animals are inside such facility. When compared to conventional systems of pig farming, the creation of bed enables the reduction of costs in facilities, improving the welfare of animals and causes less harm to the environment (CORREAA et al., 2008; COSTA et al., 2008; CORRÊA et al., 2009).

Besides these advantages, GIACOMINI \& AITA (2008a) also pointed out that the treatment of waste in deep litter system promotes the generation of a solid compound with fertilizer potential still little understood, that, according to BARTELS (2001), features over $30 \%$ of dry matter, enabling greater agronomic recovery of waste managed in deep litter systems.

The use of pig manure as fertilizer in corn appears as a very interesting proposal for recycling these wastes contributing to the sustainability of the production system, since, according to SILVA et al. (2006) and ORRICO JÙNIOR et al. (2010), corn is the main ingredient used in swine diets.

In order to show all their productive potential, the corn crop requires that their nutritional requirements are fully met, in addition to factors such as luminosity, water availability and control of pests and diseases (BERENGUER et al., 2008). Among the nutrients required by the crop, $\mathrm{N}$ is required in larger quantities (BERENGUER et al., 2008; PAVINATO et al., 2008). However, nitrogen fertilization is rather costly for the production of corn (BERENGUER et al., 2009), reinforcing the interest for the application of organic waste as a source of nitrogen to crops.

In addition to the higher content of dry matter, deep litter system is characterized by a higher proportion of $\mathrm{N}$ present in organic form. This compound will provide greater efficiency as a source of $\mathrm{N}$ for crops when compared with pig manure, due to the expected timing of the mineralization of organic $\mathrm{N}$ from the bed to the demand of $\mathrm{N}$ by crops (GIACOMINI \& AITA, 2008a). Its application with a minimum of 15 days before planting is recommended (CFSEMG, 1999).

Given the above, the objective of this study was to evaluate the effects of nitrogen fertilization in the form of pig deep litter for the production of dry matter accumulation of nutrients by corn. 


\section{MATERIAL AND METHODS}

The production system of pigs in deep litter was destined for animals in the finishing phase, located in the satellite city of Samambaia - Federal District (DF), Brazil, whose geographical coordinates are $15^{\circ} 46^{\prime} 48^{\prime \prime}$ South and 47 $55^{\prime} 48^{\prime \prime}$ West.

Facilities of that system had east-west orientation, ceiling height of $3.0 \mathrm{~m}, 120.0 \mathrm{~m}$ long and $14.0 \mathrm{~m}$ wide and covered in clay tiles arranged in a gable ceiling and $1.50 \mathrm{~m}$ of eaves.

These facilities were divided into four stalls of 30.0m long composed of two parts. The bigger part was $11.20 \mathrm{~m}$ wide, composed of dirt floor, and was placed with a layer of carbonaceous material of about $0.50 \mathrm{~m}$ thick. The smaller part, on one side of the shed, called concrete platform, with $2.80 \mathrm{~m}$ of width, had the drinkers and feeders. This platform had a fit to the opposite side of the bed, so that the water does not interfere with the decomposition of the deep litter. The stocking density was 1.4 animals per $\mathrm{m}^{2}$ (in the bed area).

At the end of the cycle period of 95 days the premises were displaced and subjected to the processes of cleaning, disinfection and seven days of fallowing. Also in this period, the bed was rolled in order to promote aeration and mixing of the material.

To meet the objectives of this study, an experiment was conducted in a greenhouse of the Agronomy Department of the Federal University of Jequitinhonha and Mucuri Valleys, during the months from August to October, in a Quartzarenic Neosol (EMBRAPA, 2006), collected in the surface layer (0-0.20m) of the municipality of Diamantina, state of Minas Gerais (MG), Brazil, which had its clods broken, was air dried and passed through a sieve of $5 \mathrm{~mm}$ of aperture. A subsample was taken and passed through a sieve of $2 \mathrm{~mm}$ of aperture, thus constituting a thin air dried land for chemical analysis (SILVA, 2009) and soil texture (EMBRAPA, 1997). The results are shown in Table 1.

The soil was incubated in plastic pots with $\mathrm{CaCO}_{3}$ and $\mathrm{MgCO}_{3}$ p.a. at a ratio of Ca:Mg of 3:1 (RAIJ, 1991). The added amount of correction was calculated by incubation curve method, with a dosage enabling the soil to reach a $\mathrm{pH}$ in water of 6.0 (SOUZA et al., 2007). The soil remained incubated for 30 days under the equivalent humidity of $60 \%$ of the total pore volume (FREIRE et al., 1980), controlled by daily weighing.

The organic fertilizer used was pig deep litter (CSS). The carbonaceous material was used as a bed rice husk. After the passage of three consecutive batches of pigs, the CSS has undergone a maturation period of 50 days, and bed samples were taken from various points in the installation to obtain a representative composite sample. Were then performed analyzes of agronomic value in the Laboratory for the Study of Soil Organic Matter (LEMOS), of the Federal University of Lavras - MG, according to the methods described by TEDESCO et al. (1995) e MELO \& SILVA (2008).

TABLE 1. Chemical and granulometric analysis of the soil before the experiment.

\begin{tabular}{|c|c|}
\hline Characteristics & Value \\
\hline $\mathrm{pH}$ in $\mathrm{H}_{2} \mathrm{O}(1: 2,5)^{(1)}$ & 5.6 \\
\hline $\mathrm{P}\left(\mathrm{mg} \mathrm{dm}^{-3}\right)^{(1)}$ & 3.5 \\
\hline $\left.\mathrm{K}(\mathrm{mg} \mathrm{dm})^{-3}\right)^{(1)}$ & 14 \\
\hline $\mathrm{Ca}\left(\mathrm{mmol}_{\mathrm{c}} \mathrm{dm}^{-3}\right)^{(1)}$ & 13 \\
\hline $\operatorname{Mg}\left(\mathrm{mmol}_{\mathrm{c}} \mathrm{dm}^{-3}\right)^{(1)}$ & 4 \\
\hline $\mathrm{Al}\left(\mathrm{mmol}_{\mathrm{c}} \mathrm{dm}^{-3}\right)^{(1)}$ & 2 \\
\hline $\mathrm{t}\left(\mathrm{mmol}_{\mathrm{c}} \mathrm{dm}^{-3}\right)^{(2)}$ & 19 \\
\hline $\mathrm{T}\left(\mathrm{mmol}_{\mathrm{c}} \mathrm{dm}^{-3}\right)^{(3)}$ & 75 \\
\hline $\mathrm{m}(\%)^{(4)}$ & 10 \\
\hline $\mathrm{V}(\%)^{(5)}$ & 23 \\
\hline M.O. $\left(\mathrm{g} \mathrm{dm}^{-3}\right)^{(1)}$ & 12 \\
\hline Water $\left(\mathrm{g} \mathrm{kg}^{-1}\right)^{(6)}$ & 860 \\
\hline Silt $\left(\mathrm{g} \mathrm{kg}^{-1}\right)^{(6)}$ & 30 \\
\hline Clay $\left(\mathrm{g} \mathrm{kg}^{-1}\right)^{(6)}$ & 110 \\
\hline
\end{tabular}


The experimental design was completely randomized with five replications. The treatments consisted of application of dosages of $0,75,150$ and $300 \mathrm{mg} \mathrm{dm}^{-3}$ of $\mathrm{N}$ as deep litter in pots with corn, and an additional treatment with ammonium sulfate at a dosage of $150 \mathrm{mg} \mathrm{dm}^{-3}$ of $\mathrm{N}$. Dosages of soil CSS $\mathrm{N}$ were mixed and homogenized with their respective pots. Fertilization with ammonium sulfate was split into five topdressing applications and the first implementation occurred ten days after corn emergence and other applications were performed at intervals of seven days. The experimental units were composed of plastic pots of $5 \mathrm{dm}^{3}$, not drilled, and received $4 \mathrm{dm}^{3}$ of dry soil.

Both soils of pots that received increasing dosages of $\mathrm{N}$ as deep litter, and the soil of the pots were subjected to further treatment of basic seeding fertilization, which consisted of, according to MALAVOLTA (1980), 150mg of P, $150 \mathrm{mg}$ of K,1.0mg of B, $1.5 \mathrm{mg}$ of $\mathrm{Cu}, 5.0 \mathrm{mg}$ of $\mathrm{Fe}, 4.0 \mathrm{mg}$ of $\mathrm{Mn}$ and $5.0 \mathrm{mg}$ of $\mathrm{Zn}$ per $\mathrm{dm}^{3}$ of soil. The sources used were p.a. reagents: $\mathrm{NaH}_{2} \mathrm{PO}_{4}, \mathrm{KCl} ; \mathrm{H}_{3} \mathrm{BO}_{3}$; $\mathrm{CuCl}_{2} .5 \mathrm{H}_{2} \mathrm{O} ; \mathrm{FeSO}_{4} \cdot 7 \mathrm{H}_{2} \mathrm{O}$-EDTA; $\mathrm{MnCl}_{2} \cdot \mathrm{H}_{2} \mathrm{O}$ and $\mathrm{ZnSO}_{4} \cdot 7 \mathrm{H}_{2} \mathrm{O}$. Soil samples were again incubated for 30 days, and the same previous moisture levels were kept. Then, five corn seeds (Zea mays L.), of the variety BR-206, were sown per pot. After seedling emergence, thinning was done leaving only one seedling per pot. The harvest of corn plants was carried out in the vegetative phenological stage V9 with nine fully developed leaves at 45 days after sowing.

At the end of the experiment, the separation of roots and aerial parts of corn plants was performed by cutting them close to the ground. Both the aerial parts as the roots were washed with tap water and distilled water. They were then weighed and placed to dry for 72 hours in an oven with forced air circulation at $65^{\circ} \mathrm{C}$. After oven drying, the plant material was weighed again and ground.

During the corn harvest, the nutrients in the aboveground part of the plant were evaluated according to the methodology described by MALAVOLTA et al. (1997). The nutrients evaluated in the aerial parts of corn were nitrogen $(\mathrm{N})$, phosphorus $(\mathrm{P})$, potassium $(\mathrm{K})$, calcium $(\mathrm{Ca})$, magnesium $(\mathrm{Mg})$, sulfur $(\mathrm{S})$, boron $(\mathrm{B})$, copper $(\mathrm{Cu})$, iron $(\mathrm{Fe})$, manganese $(\mathrm{Mn})$ and zinc $(\mathrm{Zn})$.

The data obtained of dry matter of the total dry matter (dry matter of aerial parts + roots) and nutrients in the aboveground part of corn plants were subjected to analysis of variance and regression, with significance level of $5 \%$ probability, which, at this stage, we employed the statistical program SISVAR (FERREIRA, 2003).

\section{RESULTS AND DISCUSSION}

\section{Dry matter production}

The application of $\mathrm{N}$ levels through pig deep litter (CSS) linearly increased the total dry matter yield (Figure 1). Significant increases in dry matter yield of vegetable overseeded pastures and fertilized with two types of deep litter systems (wood shavings and -rice husk) were also evidenced by HENTZ et al. (2008).

The increase in dry matter production due to the increase in dosages of deep litter can be attributed to the fact the soil is sandy and low in organic matter, with direct response, which associated with the amount of macro and micronutrients given in higher doses led to chemical conditions favorable to the development of corn, as also found LIMA et al. (2007a).

TAM (1995) investigated the use of pig deep litter as a source of nutrients for growing Brassica parachinensis and also found that this residue significantly increased the dry matter production of the plant. 


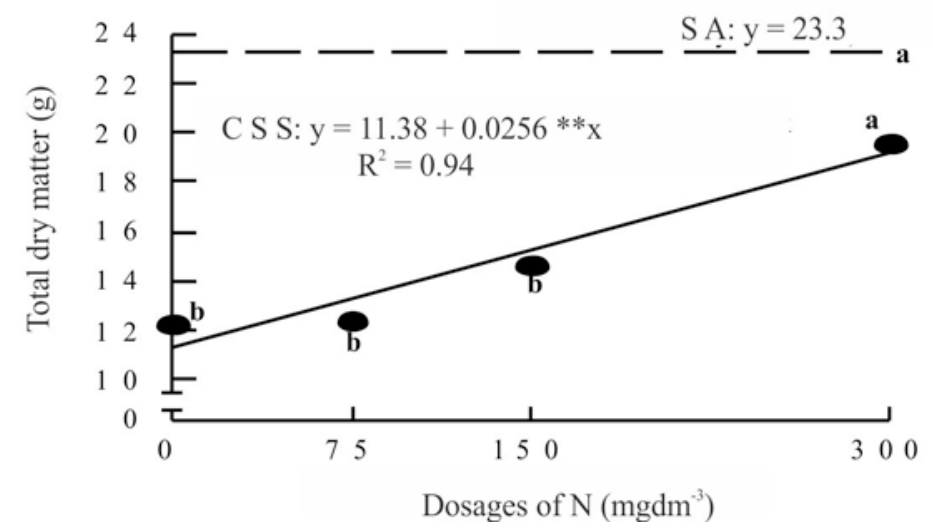

FIGURE 1. Production of total dry matter of corn plants as a function of $\mathrm{N}$ as pig deep litter (CSS) and mineral fertilization with ammonium sulfate (AS).

**Significative at $1 \%$ by the T test. Averages followed by the same letter do not differ among themselves by Scott-Knott test at 5\%.

\section{Nutrient content in the aerial parts of corn}

The results obtained for $\mathrm{N}$ content in the aerial parts of corn (Figure 2a) showed no significant response of dosages of $\mathrm{N}$ via CSS compared to control fertilization, whereas symptoms of $\mathrm{N}$ deficiency were observed in corn that received dosages this nutrient in the form of CSS. Similarly, TAM (1995) also found low concentrations of nitrogen in plants of Brassica parachinensis subjected to fertilization of pig deep litter.

In this context, the possibility of gradual mineralization of organic $\mathrm{N}$, added by CSS, to promote synchrony between $\mathrm{N}$ supplies to $\mathrm{N}$ demand of corn, was not confirmed in this study. According to GIACOMINI et al. (2009), it indicates that the organic $\mathrm{N}$ in bed has a low rate of mineralization and/or microbial decomposers of organic material that carbonaceous compounds immobilized part of the $\mathrm{N}$ of their waste and also soil.

GIACOMINI \& AITA (2008a), with the objective of evaluating the dynamics of $\mathrm{N}$ in the soil and supply of this nutrient to corn by liquid waste and by pig deep litter showed that the capability of overlaying the $\mathrm{N}$ supply is far short of the bed results found with urea and liquid waste.

In this study, the smallest values of $\mathrm{N}$ found in the aerial parts of plants receiving this nutrient in the form of deep litter, can also be justified by the losses by volatilization of the bed, which already occurs within the premises. Accordingly, such losses decreased the mean potential fertilizing of the deep litter, for approximately 40 to $70 \%$ of $\mathrm{N}$ of pig residues in ammoniacal form (AITA et al., 2006a; AITA et al., 2006b; GIACOMINI et al., 2006; AITA et al., 2007; GIACOMINI et al., 2009). 
(a)

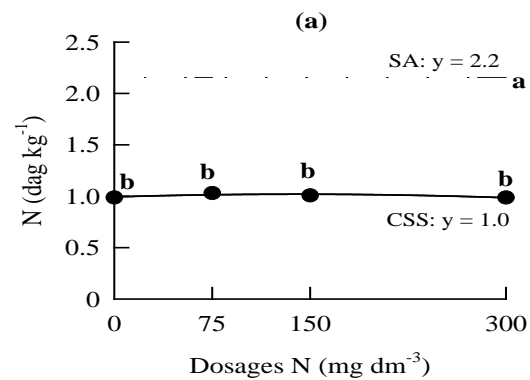

(d)

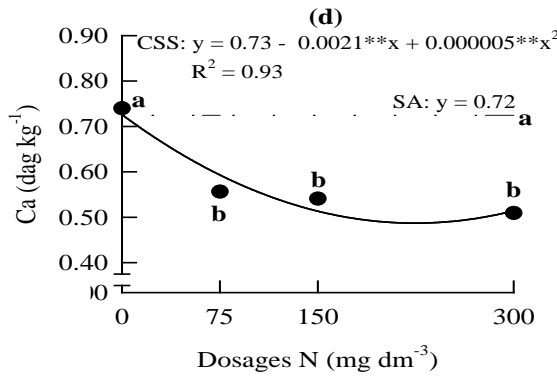

(g) $0.009 * * x$
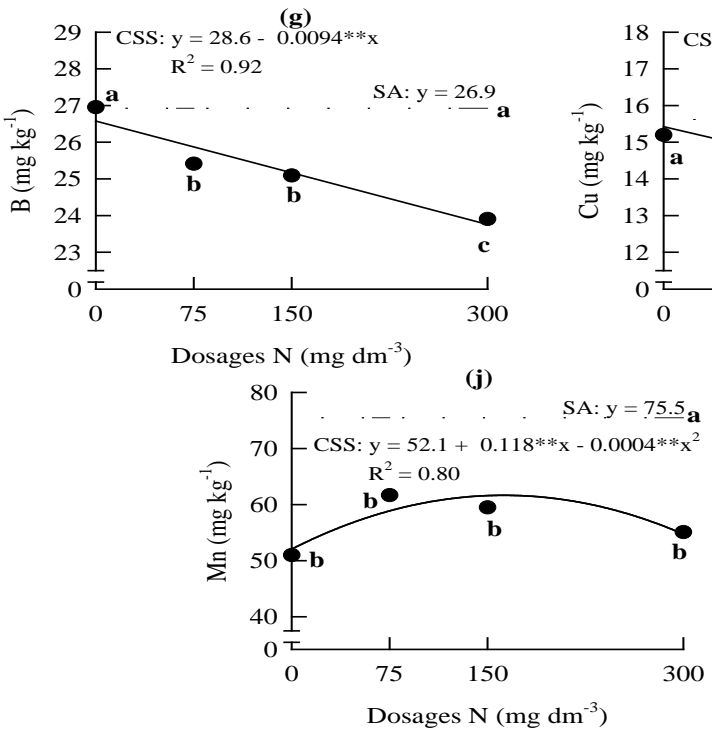

(b)

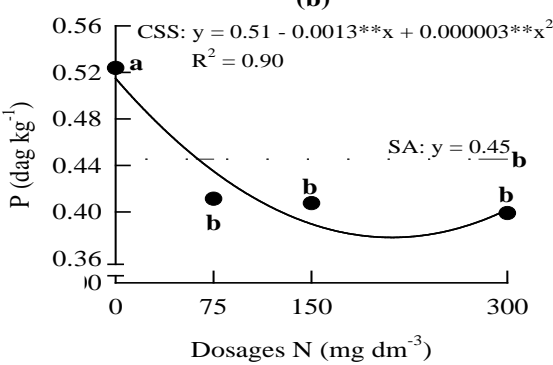

(e)

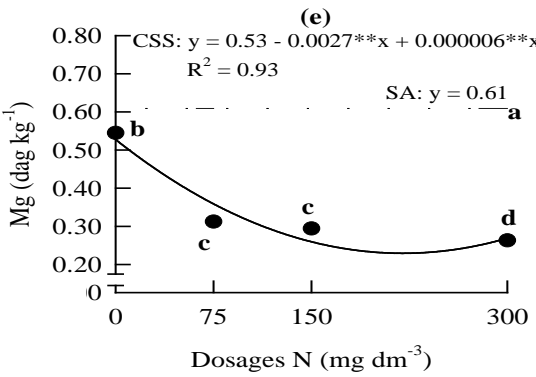

(h)

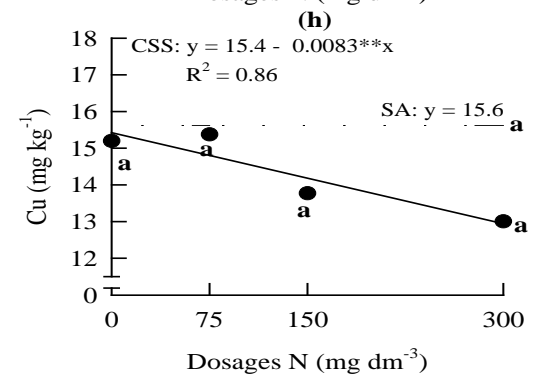

Dosages $\mathrm{N}\left(\mathrm{mg} \mathrm{dm}^{-3}\right)$

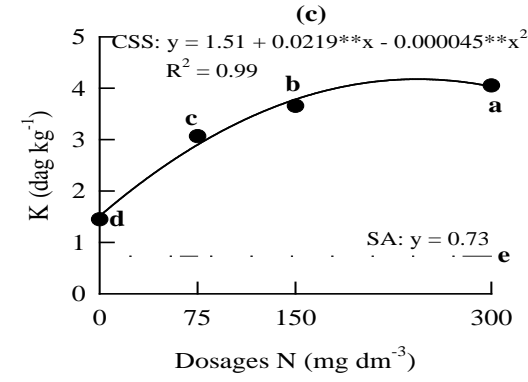

(f)

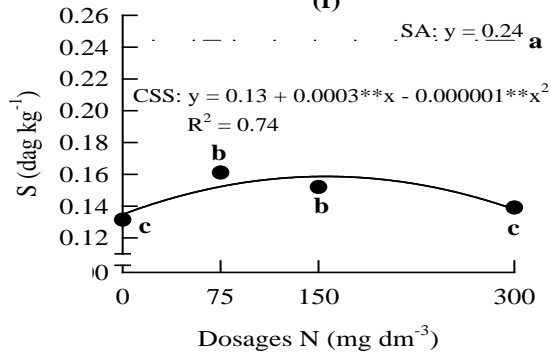

(i)

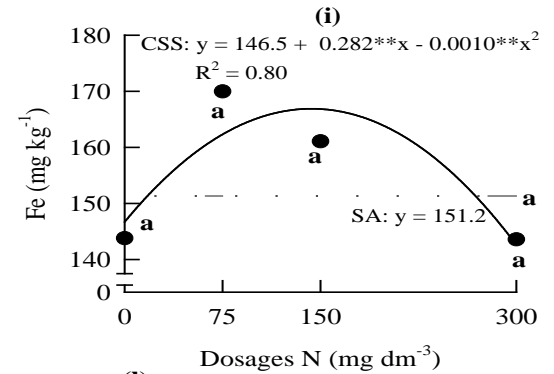

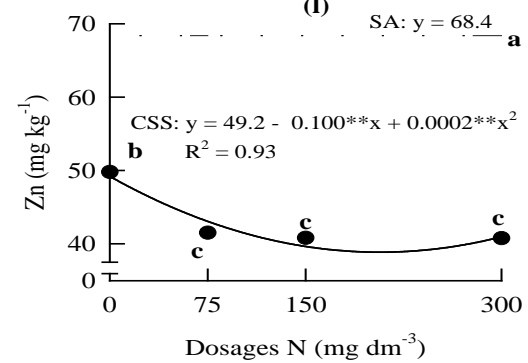

FIGURE 2. Nutrient content of corn plants as a function of $\mathrm{N}$ as pig deep litter (CSS) and mineral fertilization with ammonium sulfate (AS).

**Significative at $1 \%$ by the $T$ test. Averages followed by the same letter do not differ among themselves by Scott-Knott test at 5\%.

Studying the accumulation of nutrients and heavy metals in wood shaving deep litter, HIGARASHI et al. (2008) found that the reactions of nitritation and nitrification (conversion of ammonia to nitrite and/or nitrate) that already occur within the premises, provided lower accumulation of $\mathrm{N}$ in the residue.

The results of this study showed that nitrogen in the form of CSS did not allow an increase in $\mathrm{P}$ concentration in the aerial parts of corn, on the contrary, organic fertilization reduce the levels of $\mathrm{P}$ fertilization compared to control (Figure 2b). BARNABAS et al. (2007) found low levels of P in Brachiaria brizantha cv. Marandu fertilized with pig liquid waste. These researchers explain that, possibly, the study period was not sufficient for organic phosphorus found in manure became accessible to plants, since the transformation of this mineral in the soil orthophosphate is necessary so that the plants can take advantage of it.

In a research conducted by CERETTA et al. (2005), it was found that P had the lowest percentage of recovery by corn, which can be explained by the smaller amount required by the crop, and that most of the manure $\mathrm{P}$ is part of organic compounds, not being readily available to plants. The slow mineralization of organic matter (maintaining more constant organic $\mathrm{P}$ ) is guaranteed a 
more gradual supply, as a "slow release fertilizer" of $\mathrm{P}$ and other nutrients for excellent plant growth (NOVAIS et al., 2007).

Therefore, it is concluded that the experimental period was not sufficient to form the mineralization of available $\mathrm{P}$ for plants.

Corn plants had high content of $\mathrm{K}$ in the aerial parts, in the treatments that received dosages of $\mathrm{N}$ via CSS, as it increased the levels of this residue (Figure 2c). Thus, it can be concluded that the CSS evaluated in this study is an excellent source of potassium. It is characteristic of $K$ to accumulate in plants above the required amount. The increase in $\mathrm{K}$ content in aerial parts of corn in treatments with dosages of deep litter can be explained by the large demand for corn and the fact that almost all $\mathrm{K}$ present in the manure is readily available to plants (CERETTA et al., 2005). Another factor that reinforces the largest accumulation of $\mathrm{K}$ in the aerial parts of corn is the fact that before the establishment of the experiment, the levels of this nutrient in the soil were $14 \mathrm{mg} \mathrm{dm}^{3}$, which is considered too low by CFSEMG et al. (1999).

The polynomial regression curve shows that the levels of $\mathrm{Ca}$ and $\mathrm{Mg}$ in the aerial parts of corn did not increase with dosages of $\mathrm{N}$ in the form of deep litter, however, when compared with the control system, it was noted decrease in organic fertilization $\mathrm{Ca}$ and $\mathrm{Mg}$ (Figure 2d and 2e). However, in this study, significant increases in $\mathrm{K}$ concentration in aerial parts of corn were found with the application of increasing dosages of CSS (Figure 2c) increments. Thus, as pointed out by MALAVOLTA et al. (1997), high concentrations of $\mathrm{K}$ in the soil solution could competitively inhibit the absorption of calcium and, especially, of $\mathrm{Mg}$ by plant roots.

The polynomial regression for dosages of CSS showed that there was an increase of sulfur content (S) in corn with the application of the compound. The dosage of $150 \mathrm{mg} \mathrm{dm}^{-3}$ of N as CSS favored a higher $S$ content in the aerial parts of corn (Figure 2f), although the effect of organic manure for that content was not significant compared to the control. One possible explanation for this behavior is the fact that the rate and extent of mineralization of $\mathrm{S}$ of the deep litter is less dependent on the $\mathrm{C}$ mineralization than $\mathrm{N}$ mineralization process, since $\mathrm{S}$ can be released from organic matter by biochemical processes, via the enzymatic hydrolysis of sulfate esters (SILVA et al. 1999).

In this paper, for $\mathrm{Cu}$ and $\mathrm{Zn}$, the addition of $\mathrm{N}$ through the CSS did not cause significant accumulation $(\mathrm{P}<0.05)$ of these elements in the aerial parts of corn (Figure $2 \mathrm{~h}$ and $2 \mathrm{l})$. However, it was found a higher content of these micronutrients in plants of the control treatment and a slight reduction in the plants that received organic fertilization (Figure $2 \mathrm{~h}$ and $2 \mathrm{l}$ ).

The decrease in the levels of $\mathrm{Cu}$ and $\mathrm{Zn}$ with $\mathrm{N}$ application through the deep litter were probably due to complexation and/or by chelatization of organic matter, organic compounds of low and high molecular weight (SHUMAN, 1999), with low availability to corn plants due to the reduced trial period for digestion of the deep litter.

SILVA et al. (2007) evaluated the effects of the application of municipal solid waste, or not enriched with heavy metals, in the cultivation of sugarcane and concluded that $\mathrm{Cu}$ is an element of concern, since it is very mobile and has high speed of passage, if not immobilized in soil organic matter.

The organic fertilization with CSS enabled corn plants to accumulate higher amounts of Fe and $\mathrm{Mn}$ compared to plants of the control treatment (Figure $2 \mathrm{i}$ and $2 \mathrm{j}$ ), with a higher content of Fe and $\mathrm{Mn}$ at the dosage of 141 and $148 \mathrm{mg} \mathrm{dm}^{-3}$ of $\mathrm{N}$ as CSS, respectively. According to SANTOS \& RODELLA (2007), higher levels of Fe and Mn in corn under application of CSS, could be justified by the formation of soluble organic complexes, especially low molecular weight, organic matter. In most cases, the organic material to a lesser extent affects the availability of Fe and Mn in the $\mathrm{Zn}$ and especially to $\mathrm{Cu}$. On the other hand, with larger dosages may be CSS complexation of Fe and $\mathrm{Mn}$ containing organic compounds of high molecular weight (humic substances) of more stable forms with these metals (SHUMAN 1999). 
Regarding the content of boron (B) in the aerial parts of corn, it was found that there was significant difference between $\mathrm{N}$ fertilization in the form of CSS and the control (Figure 2g). As reported by LIMA et al. (2007b), this can be explained by the greater availability of B is associated with sandier soils and/or low in organic matter texture. With the increasing levels of CSS decreased the levels of B due to the fact that soil organic matter adsorbs (on a weight basis) more B than mineral soil constituents (GOLDBERG, 1997). The complexation of the organic material may occur with the formation of B-diol complexes resulting from the breakdown of components of the organic matter or of the connection a-hydroxy carboxylic acid to the organic matter (YERMIYAHO et al., 1988; GOLDBERG, 1997).

\section{CONCLUSION}

Compared to control fertilization, it is concluded that, statistically, the use of increasing dosages of CSS enabled $\mathrm{K}$ accumulation, reduced availability of $\mathrm{P}, \mathrm{Ca}, \mathrm{Mg}, \mathrm{B}$ and $\mathrm{Zn}$, and did not alter the concentrations of N, Cu, Fe and Mn.

Regarding dry matter accumulation, it was growing and statistically equal to the treatment that used a mineral fertilizer.

\section{ACKNOWLEDGEMENTS}

The authors thank CNPq for the financial support.

\section{REFERENCES}

AITA, C.; GIACOMINI, S.J. Nitrato no solo com a aplicação de dejetos líquidos de suínos no milho em plantio direto. Revista Brasileira de Ciência do Solo, Viçosa-MG, v.32, n.5, p.2101-2111, set/out. 2008.

AITA, C.; GIACOMINI, S.J.; HÜBNER, A.P. Nitrificação do nitrogênio amoniacal de dejetos líquidos de suínos em solo sob sistema de plantio direto. Pesquisa Agropecuária Brasileira, Brasília, v.42, n.1, p.95-102, jan. 2007.

AITA, C.; CHIAPINOTTO, I.C.; GIACOMINI, S.J. et al. Decomposição de palha de aveia preta e dejetos de suínos em solo sob plantio direto. Revista Brasileira de Ciência do Solo, Viçosa-MG, v.30, n.1, p.149-161, jan/fev. 2006a.

AITA, C.; PORT, O.; GIACOMINI, S.J. Dinâmica do nitrogênio no solo e produção de fitomassa por plantas de cobertura no outono/inverno com o uso de dejetos de suínos. Revista Brasileira de Ciência do Solo, Viçosa-MG, v.30, n.5, p.901-910, set/out. 2006b.

ANGONESE, A.R.; CAMPOS, A.T.; WELTER, R.A. Potencial de redução de emissão de equivalente de carbono de uma unidade suinícola com biodigestor. Engenharia Agrícola, Jaboticabal, v.27, n.3, p.648-657, set./dez. 2007.

ANGONESE, A.R.; CAMPOS, A.T.; ZACARKIM, C.E. et al. Eficiência energética de sistema de produção de suínos com tratamento dos resíduos em biodigestor. Revista Brasileira de Engenharia Agrícola e Ambiental, Campina Grande, v.10, n.3, p.745-750, jul./set. 2006.

BARNABÉ, M.C.; ROSA, B.; LOPES, E.L. et al. Produção e composição químico-bromatológica da Brachiaria brizantha CV. Marandu adubada com dejetos líquidos de suínos. Ciência Animal Brasileira, Goiânia, v.8, n.3, p.435-446, jul./set. 2007.

BARTELS, H. Criação de suíno sobre cama. Agroecologia e Desenvolvimento Rural Sustentável, Porto Alegre, v.2, n.2, p.27-29, abr/jun. 2001.

BASSO, C.J.; CERETTA, C.A.; DURIGON, R. et al. Dejeto líquido de suínos: II - perdas de nitrogênio e fósforo por percolação no solo sob plantio direto. Ciência Rural, Santa Maria, v.35, n.6, p.1305-1312, nov./dez. 2005. 
BERENGUER, P.; SANTIVERI, F.; BOIXADERA, J. et al. Fertilisation of irrigated maize with pig slurry combined with mineral nitrogen. European Journal of Agronomy, Amsterdam, v.28, n.4, p.635-645, may 2008.

BERENGUER, P.; SANTIVERI, F.; BOIXADERA, J. et al. Nitrogen fertilisation of irrigated maize under Mediterranean conditions. European Journal of Agronomy, Amsterdam, v.30, n.3, p.163-171, apr. 2009.

CERETTA, C.A.; BASSO, C.J.; PAVINATO, P.S. et al. Produtividade de grãos de milho, produção de matéria seca e acúmulo de nitrogênio, fósforo e potássio na rotação aveia preta/milho/nabo forrageiro com aplicação de dejeto líquido de suínos. Ciência Rural, Santa Maria, v.35, n.6, p.12871295, nov./dez. 2005.

CFSEMG. COMISSÃO DE FERTILIDADE DO SOLO DO ESTADO DE MINAS GERAIS. Adubação orgânica. In: RIBEIRO, A. C.; GUIMARÃES, P. T. G.; ALVAREZ V., V. H. (Ed.). Recomendações para o uso de corretivos e fertilizantes em Minas Gerais. Viçosa: CFSEMG, 1999. p. 87-92.

CORDEIRO, M.B.; TINÔCO, I.F.F.; OLIVEIRA, P.A.V. et al. Efeito de sistemas de criação no conforto térmico ambiente e no desempenho produtivo de suínos na primavera. Revista Brasileira de Zootecnia, Viçosa-MG, v.36, n.5, p.1597-1602, set./out. 2007.

CORRÊA, E.K.; BIANCHI, I.; PERONDI, A. et al. Chemical and microbiological characteristics of rice husk bedding having distinct depths and used for growing-finishing swine. Bioresource Technology, Essex, v.100, n.21, p.5318-5322, nov. 2009.

CORRÊA, E.K.; LUCIA JÚNIOR, T.; GIL-TURNES, C. et al. Efeito de diferentes profundidades de cama sobre parâmetros ambientais para suínos em crescimento e terminação. Revista Brasileira de Engenharia Agrícola e Ambiental, Campina Grande, v.12, n.5, set./out. 2008.

COSTA, O.A.D.; AMARAL, A.L. do; LUDKE, J.V. et al. Desempenho, características de carcaça, qualidade da carne e condição sanitária de suínos criados nas fases de crescimento e terminação nos sistemas confinado convencional e de cama sobreposta. Ciência Rural, Santa Maria, v.38, n.8, p.2307-2313, nov. 2008.

DAL BOSCO, T.C.; IOST, C.; SILVA, L.N. et al. Utilização de água residuária de suinocultura em propriedade agrícola - estudo de caso. Irriga, Botucatu, v.13, n.1, p.139-144, jan./mar. 2008a.

DAL BOSCO, T.C.; SAMPAIO, S.C.; OPAZO, M.A.U. et al. Aplicação de água residuária de suinocultura em solo cultivado com soja: cobre e zinco no material escoado e no solo. Engenharia Agrícola, Jaboticabal, v.28, n.4, p.699-709, out./dez. 2008b.

EMBRAPA. Centro Nacional de Pesquisa de Solos (Rio de Janeiro, RJ). Sistema brasileiro de classificação de solos. Brasília: Produção de informações, 2006. 306 p.

EMBRAPA. Centro Nacional de Pesquisa de Solos (Rio de Janeiro, RJ). Manual de métodos de análise do solo. Brasília: SPI, 1997. 212p.

FERREIRA, D.F. Sisvar: versão 4.2. Lavras: UFLA, 2003.

FREIRE, J.C.; RIBEIRO, M.A.V.; BAHIA, G.V.; LOPES, A.S.; AQUINO, L.H. Resposta do milho cultivado em casa de vegetação a níveis de água em solo da região de Lavras, MG. Revista Brasileira de Ciência do Solo, Viçosa-MG, v.4, n.1, p.5-8, 1980.

GATIBONI, L.C.; BRUNETTO, G.; KAMINSKI, J. et al. Formas de fósforo no solo após sucessivas adições de dejeto líquido de suínos em pastagem natural. Revista Brasileira de Ciência do Solo, Viçosa-MG, v.32, n.4, p.1753-1761, jul/ago. 2008.

GIACOMINI, S.J.; AITA, C. Cama sobreposta e dejetos líquidos de suínos como fonte de nitrogênio ao milho. Revista Brasileira de Ciência do Solo, Viçosa-MG, v.32, n.1, p.195-205, jan/fev. 2008a. 
GIACOMINI, S.J.; AITA, C. Emissão de dióxido de carbono após aplicação de dejetos líquidos e cama sobreposta de suínos. Pesquisa Agropecuária Brasileira, Brasília, v.43, n.1, p.107-114, jan. 2008b.

GIACOMINI, S.J.; AITA, C. JANTALIA, C.P. et al. Aproveitamento pelo milho do nitrogênio amoniacal de dejetos líquidos de suínos em plantio direto e preparo reduzido do solo. Pesquisa Agropecuária Brasileira, Brasília, v.44, n.7, p.1653-761-768, jul. 2009.

GIACOMINI, S.J.; JANTALIA, C.P.; AITA, C. et al. Emissão de dejetos líquidos de suínos em solo sob plantio direto. Pesquisa Agropecuária Brasileira, Brasília, v.41, n.11, p.1653-1661, nov. 2006.

GOLDBERG, S. Reactions of boron with soils. Plant and Soil, Dordrecht, v.193, n.1-2, p.35-48, june. 1997.

HENTZ, P.; SCHEFFER-BASSO, S.M.; ESCOSTEGUY, P.A.V. et al. Utilização de cama sobreposta de suínos e sobressemeadura de leguminosas para aumento da produção e qualidade de pastagem natural. Revista Brasileira de Zootecnia, Viçosa-MG, v.37, n.9, p.1537-1545, set. 2008.

HIGARASHI, M.M.; COLDEBELLA, A.; OLIVEIRA, P.A.V. et al. Concentração de macronutrientes e metais pesados em maravalha de unidade de suínos em cama sobreposta. Revista Brasileira de Engenharia Agrícola e Ambiental, Campina Grande, v.12, n.3, p.311-317, maio/jun. 2008.

LIMA, J.C.P.S.; NASCIMENTO, C.W.A.; LIMA, G.C. et al. Níveis críticos e tóxicos de boro em solos de Pernambuco determinados em casa de vegetação. Revista Brasileira de Ciência do Solo, Viçosa-MG, v.31, n.1, p.73-79, jan/fev. 2007b.

LIMA, J.J.; MATA, J.D.V.; PINHEIRO NETO, R. et al. Influência da adubação orgânica nas propriedades químicas de um latossolo vermelho distrófico e na produção de matéria seca de Brachiaria brizantha cv. Marandu. Acta Scientiarum Agronomy, Maringá, v.29, p.715-719, 2007a. Suplemento.

LIMON-ORTEGA, A.; GOVAERTS, B.; SAYRE, K.D. Straw management, crop rotation, and nitrogen source effect on wheat grain yield and nitrogen use efficiency. European Journal of Agronomy, Amsterdam, v.29, n.1, p.21-28, jul. 2008.

MALAVOLTA, E. Elementos de nutrição mineral de plantas. Piracicaba: Ceres, 1980. 252p.

MALAVOLTA, E.; VITTI, G. C.; OLIVEIRA, S. A. Avaliação do estado nutricional das plantas: princípios e aplicações. 2. ed. Piracicaba: POTAFOS, 1997. 319 p.

MELO, L.C.A.; SILVA, C.A. Influência de métodos de digestão e massa de amostra na recuperação de nutrientes em resíduos orgânicos. Química Nova, São Paulo, v.31, n.3, p.556-561, 2008.

NOVAIS, R.F.; SMYTH, T.J.; NUNES, F.N. Fósforo. In: NOVAIS, R.F.; ALVAREZ V., V.H.; BARROS, N.F. et al. (ed.). Fertilidade do solo. Viçosa: SBCS, 2007. p.471-537.

NUNES, M.A.G.; KUNZ, A.; STEINMETZ, R.L.R. et al. Aplicação de efluente tratado de suinocultura para diluição de dejeto suíno e remoção de nitrogênio por desnitrificação. Engenharia Agrícola, Jaboticabal, v.31, n.2, p.388-398, mar./abr. 2011.

ORRICO JÚNIOR, M.A.P.; ORRICO, A.C.A.; LUCAS JÚNIOR, J. Avaliação de parâmetros da biodigestão anaeróbia de dejetos de suínos alimentados com dietas à base de milho e sorgo.

Engenharia Agrícola, Jaboticabal, v.30, n.4, p. 600-607, jul./ago. 2010

ORRICO JÚNIOR, M.A.P.; ORRICO, A.C.A.; LUCAS JÚNIOR, J. Compostagem da fração sólida da água residuária de suinocultura. Engenharia Agrícola, Jaboticabal, v.29, n.3, p.483-491, jul./set. 2009. 
PAVINATO, P.S.; CERETTA, C.A.; GIROTTO, E. et al. Nitrogênio e potássio em milho irrigado: análise técnica e econômica da fertilização. Ciência Rural, Santa Maria, v.38, n.2, p.358-364, mar/abr. 2008.

RAIJ, B. van. Avaliação da fertilidade do solo. Piracicaba: POTAFOS, 1991. 343p.

SAMPAIO, S.C.; CAOVILLA, F.A.; OPAZO, M.A.U. et al. Lixiviação de íons em colunas de solo deformado e indeformado. Engenharia Agrícola, Jaboticabal, v.30, n.1, p.150-159, jan./fev. 2010.

SANTOS, G.C.G.; RODELLA, A.A. Efeito da adição de fontes de matéria orgânica como amenizantes do efeito tóxico de B, Zn, Cu, Mn e PB no cultivo de Brassica juncea. Revista Brasileira de Ciência do Solo, Viçosa, v.31, n.4, p.793-804, jul./ago. 2007.

SANTOS, M.A.A.; SCHMIDT, V.; BITENCOURT, V.C. Esterqueiras: avaliação físico-química e microbiológica do dejeto suíno armazenado. Engenharia Agrícola, Jaboticabal, v.27, n.2, p.537543, maio/ago. 2007.

SEDIYAMA, M.A.N.; VIDIGAL, S.M.; PEDROSA, M.W. et al. Fermentação de esterco de suínos para uso como adubo orgânico. Revista Brasileira de Engenharia Agrícola e Ambiental, Campina Grande, v.12, n.6, p.638-644, nov./dez. 2008.

SHUMAN, L.M. Organic waste amendments effect of zinc fractions of two soils. Journal of Environmental Quality, Madison, v.28, n.5, p.1442-1447, 1999.

SILVA, C.A.; VALE, F.R.; ANDERSON, S.J. et al. Mineralização de nitrogênio e enxofre em solos brasileiros sob influência da calagem e fósforo. Pesquisa Agropecuária Brasileira, Brasília, v.34, n.9, p.1679-1689, set. 1999.

SILVA, F.C. Manual de análises químicas de solos, plantas e fertilizantes. Brasília: Embrapa, 2009. 627p.

SILVA, F.C.; BERGAMASCO, A.F.; VENDITE, L.L. Modelos de transferência de metal pesado na cana-de-açúcar adubada com composto de lixo urbano. Engenharia Agrícola, Jaboticabal, v.27, n.1, p.119-128, jan./abr. 2007.

SILVA, M.A.A.; FURLAN, A.C.; MOREIRA, I. et al . Avaliação nutricional do milho com maior teor de óleo, nas formas de grãos secos e silagens, para suínos nas fases de crescimento e terminação. Revista Brasileira de Zootecnia, Viçosa-MG, v.35, n.3, p.830-839, maio/jun. 2006.

SMANHOTTO, A.; SOUSA, A.P.; SAMPAIO, S.C. et al. Cobre e zinco no material percolado e no solo com a aplicação de água residuária de suinocultura em solo cultivado com soja. Engenharia Agrícola, Jaboticabal, v.30, n.2, mar/abr. 2010.

SOUZA, C.V.; CAMPOS, A.T.; BUENO, O.C. et al. Análise energética em sistema de produção de suínos com aproveitamento dos dejetos como biofertilizante em pastagem. Engenharia Agrícola, Jaboticabal, v.29, n.4, p.547-557, out/dez. 2009.

SOUZA, D.M.G.; MIRANDA, L.N.; OLIVEIRA, S.A. Acidez do solo e sua correção. In: NOVAIS, R.F.; ALVAREZ V.; V.H.; BARROS, N.F.; FONTES, R.L.F.; CANTARUTTI, R.B.; NEVES, J.C.L. Fertilidade do solo. Viçosa: SBCS, 2007. p. 205-274.

TAM, N.F.Y. Spent pig litter as fertilizer for growing vegetables. Bioresource Technology, Essex, v.53, n.2, p.151-155, 1995.

TEDESCO, M.J.; GIANELLO, C.; BISSANI, C.A.; BOHNEN, H.; VOKWEISS, S.J. Análise de solo, plantas, e outros materiais. 2.ed. Porto Alegre: Universidade Federal do Rio Grande do Sul, 1995. 174p.

YERMIYAHO, U.; KEREN, R.; CHEN, Y. Boron sorption on composted organic matter. Soil Science Society American Journal, Madison, v.52, p.1309-1313, 1988. 